\title{
Growth Inhibitory Activity of Callicarpa americana Leaf Extracts Against Cutibacterium acnes
}

\author{
Rozenn M. Pineau 1t, Sarah E. Hanson ${ }^{2 t}$, James T. Lyles $^{2}$ and Cassandra L. Quave 2,3,4* \\ 1 School of Biological Sciences, Georgia Institute of Technology, Atlanta, GA, United States, ${ }^{2}$ Center for the Study of Human \\ Health, Emory College of Arts and Sciences, Atlanta, GA, United States, ${ }^{3}$ Department of Dermatology, Emory University \\ School of Medicine, Atlanta, GA, United States, ${ }^{4}$ Emory University Herbarium, Atlanta, GA, United States
}

OPEN ACCESS

Edited by:

Namrita Lall,

University of Pretoria, South Africa

Reviewed by:

Adam Matkowski,

Wroclaw Medical University, Poland Hemant K. Gautam,

Institute of Genomics and

Integrative Biology (CSIR), India

Sefirin Djiogue,

University of Yaounde I, Cameroon

*Correspondence:

Cassandra L. Quave

cquave@emory.edu

tThese authors have contributed equally to this work and share first authorship

Specialty section: This article was submitted to

Ethnopharmacology,

a section of the journal

Frontiers in Pharmacology

Received: 16 April 2019 Accepted: 19 September 2019

Published: 15 October 2019

Citation:

Pineau RM, Hanson SE, Lyles JT and Quave CL (2019) Growth Inhibitory Activity of Callicarpa americana Leaf Extracts Against

Cutibacterium acnes.

Front. Pharmacol. 10:1206. doi: 10.3389/fphar.2019.01206
Acne vulgaris is a common skin disease affecting adolescents and young adults of all ethnic groups, negatively impacting self-esteem, self-confidence, and social life. The Gram-positive bacteria Cutibacterium acnes colonizes the sebum-rich follicle and contributes to inflammation of the pilosebaceous gland. Long-term antibiotic therapies targeting $C$. acnes lead to the development of antimicrobial resistance, and novel acne vulgaris therapies are needed. This study investigated the $C$. acnes inhibitory activity of Callicarpa americana leaves, a native Southeastern United States shrub historically used by Native Americans to treat fever, stomachache, and pruritis. Flash chromatography fractions of the ethyl acetate-soluble C. americana ethanol leaf extract (649C-F9 and 649C-F13) exhibited MICs ranging from 16 to $32 \mathrm{\mu g} \mathrm{ml}^{-1}$ and $\mathrm{IC}_{50}$ range of 4-32 $\mathrm{gg} \mathrm{ml}^{-1}$ against a panel of 10 distinct $C$. acnes isolates. Cytotoxicity against an immortalized human keratinocyte cell line (HaCaTs) skin was detected at more than eight times the dose required for growth inhibitory activity $\left(\mathrm{IC}_{50}\right.$ of $256 \mu \mathrm{g} \mathrm{ml}{ }^{-1}$ for $649 \mathrm{C}-\mathrm{F9}$ and $\mathrm{IC}_{50}$ of $>512 \mathrm{mg} \mathrm{ml}^{-1}$ for $\left.649 \mathrm{C}-\mathrm{F} 13\right)$. This work highlights the potential of $C$. americana leaf extracts as a cosmeceutical ingredient for the management of acne vulgaris. Further research is necessary to assess its mechanism of action and in vivo efficacy.

Keywords: medicinal plants, MIC, phytochemicals, acne, Cutibacterium acnes, biofilm, cosmeceutical

\section{INTRODUCTION}

\section{Pathogenesis of Acne Vulgaris}

Acne vulgaris is a common skin disease affecting the vast majority of adolescents and a significant proportion of young adults. Approximately $85 \%$ of the population suffers from acne vulgaris at some point in their lives (Shah and Peethambaran, 2018). Acne negatively impacts self-esteem, selfconfidence, and social life as it specifically affects the skin of the face, the chest, and the backareas where the pilosebaceous gland concentration is the highest (Thomas, 2004; Titus and Hodge, 2012). Four processes characterize acne pathogenesis: 1) follicular hyperkeratinization, 2) excess of sebum, 3) colonization of Cutibacterium acnes, and 4) inflammation and immune response (Toyoda and Morohashi, 2001). C. acnes is a Gram-positive aero-tolerant anaerobic bacteria found in the sebaceous follicle. The oxygen-poor area formed by the lipid-rich obstructed follicle makes an ideal environment for the bacteria to proliferate. Other factors such as hormonal fluctuations or imbalance, stress, and pollution can also increase inflammation by providing a suitable environment for C. acnes growth (Bhambri et al., 2009). 


\section{Current Treatment and Limitations}

Current treatments for acne vulgaris include the use of topical antibiotics and/or chemical peeling agents. Treatments can also include daily oral antibiotics, retinoids, or hormones. In the United States, topical agents predominantly prescribed in the treatment of mild to moderate acne are composed of retinoids such as differin, tazorac, or retin- $\mathrm{A}$, in combination with antibiotics such as clindamycin and erythromycin (Titus and Hodge, 2012). Benzoyl peroxide and salicylic acid are non-antibiotic therapies frequently added to creams to decrease the risk of developing antibiotic resistance and to reduce inflammation (Thiboutot et al., 2009). The most commonly used oral therapies include the tetracyclines (tetracycline, minocycline, and doxycycline), trimethoprim/sulfamethoxazole, and macrolides (erythromycin and azithromycin) (Leyden and Del Rosso, 2011).

A major disadvantage of current treatments is that daily intake of antibiotics places great selective pressure on bacteria to develop multidrug resistance (Van Den Bergh et al., 2016). Many countries have reported increasing resistance of $C$. acnes strains to topical macrolides (Walsh et al., 2016). Application of an active antibiotic gel increased resistance to erythromycin after only 12 weeks of treatment (Mills et al., 2002). The treatment of an individual's acne can also have unintended effects on the microbiome, resulting in antibiotic resistance and proliferation of opportunistic pathogens elsewhere in the body. Margolis et al. reported that development of upper respiratory tract infections and pharyngitis was more likely in patients receiving oral antibiotics (Margolis et al., 2005; Margolis et al., 2012). In light of the growing concern for increasing antibiotic resistance of $C$. acnes and other bacteria due to antibiotic use in acne treatment, alternative therapies are urgently needed.

\section{Ethnopharmacological Relevance of Callicarpa americana}

Ethnobotany is the study of plants used in different cultures, and it is a valuable framework from which to pursue drug discovery (Cox, 1994). Botanical therapies are a mixture of many active and non-active components, thus potentially having several modes of action, both direct and synergistically. The Quave Natural Product Library (QNPL) is a chemical library composed of over 1,900 plant extracts derived from 600 plant and fungal species, largely representing plants used in the traditional treatment of infectious and inflammatory skin disease. A screen of the QNPL against $C$. acnes revealed the growth inhibitory bioactivity of a crude leaf extract from Callicarpa americana L. (Lamiaceae), a native Southeastern American shrub. The Callicarpa genus has a rich history of use in traditional medicine and is characterized by the presence of biologically active terpenoids, such as monoterpenoids and diterpenoids (Kadereit, 2004). The fruits are the most striking elements of the plants in this genushence the genus name 'Callicarpa', meaning "beautiful fruit," and the common name, 'Beauty Berry'. The Alabama, Choctaw, Creek, Koasati, Seminole, and other Native American tribes used preparations of the roots, leaves, and branches for various medicinal purposes, including to treat fevers, stomachaches, and skin cancers (Taylor, 1940; Jones and Kinghorn, 2008).
Interestingly, Callicarpa species are also a key component of Asian traditional medicines ( $\mathrm{Tu}$ et al., 2013). C. arborea Roxb. was traditionally used in India to heal cuts and wounds, and C. tomentosa Lam. was used to cure boils and eczema. In China, C. macrophylla Vahl, C. pedunculata R.Br., and C. cathayana C.H.Chang were applied to the skin to heal burns and bleeds (Jones and Kinghorn, 2008), highlighting the potential effectiveness of the Callicarpa genus to treat skin diseases (Gupta et al., 2010; Bhat et al., 2014).

\section{Callicarpa americana as a Source of Antimicrobial Therapies for Acne}

Few studies have reported the bioactivity of the species $C$.

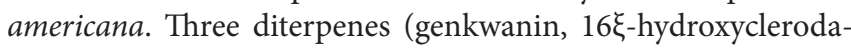
3,13-dien-15,16-olide, and 2-formyl-16 -hydroxy-3-Anorcleroda-2,13-dien-15,16-olide) were isolated from the combined fruits, leaves, and twigs (fruiting branches) of C. americana and exhibit activity against human cancer cell lines (Jones et al., 2007). Intermedeol and callicarpenal (3,14,15,16-tetranorclerodane) compounds were found in essential oils from the leaves and acted as effective deterrents of Aedes stephensi and Aedes aegypti mosquitos (Cantrell et al., 2005). Research focused on other species within the same genus, and leaf extracts of $C$. longifolia Lam. in a gel preparation were recently found to exhibit antibacterial and wound healing effects on rabbit skin (Susilawati et al., 2018). A retinoid-containing gel in combination with a C. nudiflora Hook. \& Arn. extract tablet was used in a clinical research study on acne vulgaris and was demonstrated to be more effective than the gel alone (Yang et al., 2010). These studies highlight the need for further research on C. americana extracts. In the present work, we demonstrate the promising growth inhibitory activity of C. americana on C. acnes.

\section{MATERIALS AND METHODS}

\section{Plant Collection and Identification}

Fresh leaves of $C$. americana were harvested from wild populations in Atlanta, GA, in June and August 2017. Voucher specimens (Table 1) were deposited at the Emory University Herbarium (GEO), and species identity was confirmed by botanist Tharanga Samarakoon, Ph.D. Specimens were digitized and are available for viewing on the SERNEC portal (Sernec, 2019). Bulk plant material was dried in a dehumidification chamber and then ground into a fine powder through a $2-\mathrm{mm}$ mesh with a Thomas Scientific Wiley Mill (Swedesboro, NJ). Retention vouchers of dried and ground material were prepared for future reference and stored in The Quave Research Laboratories at Emory University.

\section{Preparation of Extracts}

Dry, ground plant biomass was double macerated in 95\% ethanol at a 1:10 ratio $(w / v)$ for $72 \mathrm{~h}$ of maceration with daily agitation. The liquid was then decanted and vacuum filtered, then concentrated by rotary evaporation at $\leq 40^{\circ} \mathrm{C}$. Extracts were redissolved in $\mathrm{dH}_{2} \mathrm{O}$, shell frozen in a dry ice-acetone bath, and lyophilized overnight on a Labconco FreeZone 2.5 Lyophilizer (Kansas 
TABLE 1 | List of Callicarpa americana specimens harvested from wild populations in Atlanta, GA.

\begin{tabular}{llll}
\hline $\begin{array}{l}\text { GEO } \\
\text { accession } \\
\text { number }\end{array}$ & $\begin{array}{l}\text { Collection } \\
\text { date }\end{array}$ & Collection location & $\begin{array}{l}\text { Location } \\
\text { coordinates }\end{array}$ \\
\hline 22044 & June 26, & $\begin{array}{l}\text { Hahn Wood, Emory } \\
\text { University; USA, } \\
\text { Georgia, DeKalb }\end{array}$ & $\begin{array}{l}33.8036944440 \mathrm{~N}, \\
-84.3230833330 \mathrm{~W}\end{array}$ \\
& 2017 & $\begin{array}{l}\text { County } \\
\text { Coralwood Centre }\end{array}$ & $33.8281800000 \mathrm{~N}$, \\
22204 & Aug. 11, & $\begin{array}{l}\text { School; USA, Georgia, } \\
\text { DeKalb County }\end{array}$ & $-84.2872430000 \mathrm{~W}$ \\
& 2017 & $\begin{array}{l}\text { Coralwood Centre } \\
\text { School; USA, Georgia, }\end{array}$ & $-84.8281800000 \mathrm{~N}$, \\
& Aug. 11, & DeKalb County & \\
\hline
\end{tabular}

Voucher specimens of all populations harvested were collected and deposited the Emory University Herbarium (Index Herbariorum Code: GEO). Digitized specimens are available for viewing online through the SERNEC portal (Sernec, 2019).

City, MO). Dry crude extract (Extract ID: 649) was scraped into scintillation vials and stored at $-20^{\circ} \mathrm{C}$ until microbiological testing, at which time they were dissolved in DMSO to a stock concentration of $10 \mathrm{mg} \mathrm{ml}^{-1}$.

\section{Fractionation Strategy}

The crude extract (649) was partitioned against hexanes, ethyl acetate, $n$-butanol, and water following a modified Kupchan scheme. Subsequently, the ethyl acetate partition (649C) was determined to be the most active partition by antimicrobial bioassays and was further fractionated via flash chromatography. The full fractionation strategy is detailed in Figure 1.

Briefly, to prepare the sample, $15.36 \mathrm{~g}$ of the extract was dissolved in methanol, Celite was added at a $1: 4$ ratio $(w / w)$, the mixture was concentrated in vacuo, and the dry preparation was loaded into a Teledyne solid-phase load cartridge. A 330-g RediSep Rf Gold Silica column was used with the CombiFlash Rf+ (Teledyne ISCO) flash chromatography system. Three mobile phases-hexanes, ethyl acetate, and methanol-were used to perform the separation (Table 2 and Figure 2). The resulting tubes were combined into 31 fractions, dried in vacuo, lyophilized, scraped into scintillation vials, and then stored at $-20^{\circ} \mathrm{C}$ until testing.

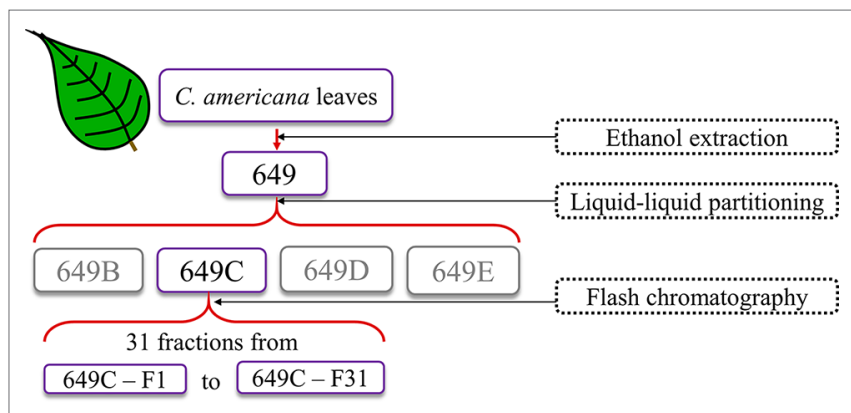

FIGURE 1 | Extraction and fractionation strategy for C. americana dried leaves.
TABLE 2 | Gradient table for the flash chromatography separation of extract 649 C.

\begin{tabular}{lccc}
\hline Minutes & \% Hexane & \% Ethyl Acetate & $\%$ Methanol \\
\hline 0 & 100 & 0 & 0 \\
4.4 & 100 & 0 & 0 \\
8.2 & 99 & 1 & 0 \\
12 & 98 & 2 & 0 \\
15.8 & 96 & 4 & 0 \\
19.6 & 91.9 & 8.1 & 0 \\
24.3 & 85.4 & 14.9 & 0 \\
38.9 & 68.1 & 31.9 & 0 \\
54.3 & 35.9 & 641 & 0 \\
69.8 & 0 & 100 & 0 \\
88.2 & 0 & 100 & 0 \\
88.4 & 0 & 100 & 0 \\
92.2 & 0 & 99 & 1 \\
96 & 0 & 98 & 2 \\
99.8 & 0 & 96 & 4 \\
103.6 & 0 & 92 & 8 \\
107.4 & 0 & 84 & 16 \\
111.2 & 0 & 70 & 30 \\
129.7 & 0 & 70 & 30 \\
133.3 & 0 & 0 & 100 \\
146.6 & 0 & 0 & 100 \\
\hline & & & \\
\hline
\end{tabular}

The flow rate for the 330-g RediSep Rf Gold Silica column was $200 \mathrm{ml} \mathrm{min}{ }^{-1}$.

\section{Antibacterial Testing \\ Bacterial Strains and Cultures}

Extracts were first tested against a C. acnes isolate obtained from the American Type Culture Collection (strain ATCC6919). Based on these results, the most active fractions and their parent extracts were tested for growth inhibitory activity in nine additional clinical isolates of $C$. acnes; strain and source details are provided in Table 3. All bacteria were streaked onto tryptic soy agar (TSA) plates supplemented with 5\% sheep blood (Hardy). Plates were incubated at $37^{\circ} \mathrm{C}$ until individual colonies were visible $(72 \mathrm{~h}$ for most isolates and $120 \mathrm{~h}$ for the slowest growers) before individual colonies were transferred into Brain Heart Infusion broth supplemented with 1\% dextrose (BHId). Liquid cultures were incubated for an additional $72 \mathrm{~h}$ before preparation of a working culture for biological assays. An EZ Anaerobe Chamber and GasPak EZ Anaerobe (BD) container sachets were used to create the anaerobic conditions required for C. acnes growth.

\section{Growth Inhibition Assays}

As no Clinical and Laboratory Standards Institute (CLSI) guidelines for MIC testing in $C$. acnes have been published, we followed a previously described microtiter broth method (Nelson et al., 2016). Liquid cultures were standardized to an optical density of 0.05 at $590 \mathrm{~nm}\left(\mathrm{OD}_{590 \mathrm{~nm}}\right)$, which corresponds to $5 \times 10^{7} \mathrm{CFU} \mathrm{ml} \mathrm{m}^{-1}$, using a Cytation-3 multimode plate reader (BioTek). This was further confirmed by plate counts. BHId was used for adjusting the final inoculum density.

The growth inhibition assay was performed in a sterile 96-well plate (Falcon 351172) in a total well volume of $200 \mu \mathrm{L}$. The dose tested ranged from 0.125 to $64 \mu \mathrm{g} \mathrm{ml}^{-1}$ for ATCC6919 and from 2 to $64 \mu \mathrm{g} \mathrm{ml}^{-1}$ for all other clinical isolates. Negative controls 


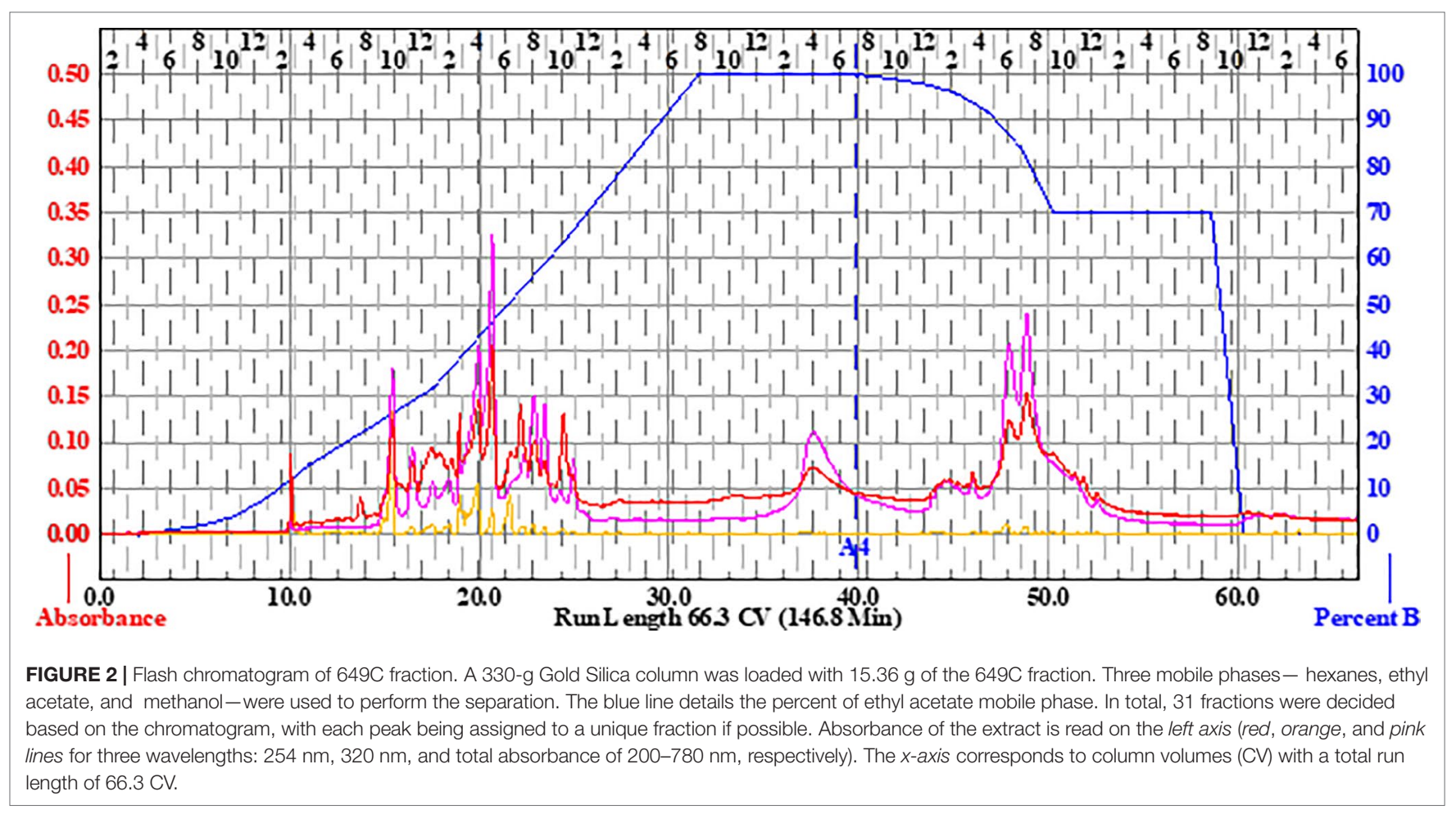

(no treatment and DMSO vehicle treatment), positive control (clindamycin treatment), and a media control (BHId alone) were included, and all treatments were conducted in triplicate and repeated on two separate days. A first $\mathrm{OD}_{600 \mathrm{~nm}}$ determination was conducted immediately following plate setup, prior to a $72-\mathrm{h}$ incubation period at $37^{\circ} \mathrm{C}$ in an anaerobe chamber. A second $\mathrm{OD}_{600 \mathrm{~nm}}$ determination was taken $72 \mathrm{~h}$ post-inoculation, and the final percent inhibition of growth was determined following a previously reported formula, which takes into account the effect

TABLE $3 \mid$ C. acnes strain details.

\begin{tabular}{|c|c|c|c|}
\hline Strain ID & $\begin{array}{l}\text { Strain } \\
\text { genotype }\end{array}$ & $\begin{array}{l}\text { Type of } \\
\text { isolate }\end{array}$ & Body site \\
\hline ATCC6919 & - & $\begin{array}{l}\text { Laboratory } \\
\text { strain }\end{array}$ & Facial acne \\
\hline B104.1 & Ribotype 3 & Clinical isolate & Nasal microcomedone \\
\hline B104.2 & Ribotype 3 & Clinical isolate & Nasal microcomedone \\
\hline B104.4 & Ribotype 3 & Clinical isolate & Nasal microcomedone \\
\hline B104.5 & Ribotype 3 & Clinical isolate & Nasal microcomedone \\
\hline B104.6 & Ribotype 1 & Clinical isolate & Nasal microcomedone \\
\hline B104.7 & Ribotype 1 & Clinical isolate & Nasal microcomedone \\
\hline B104.8 & Ribotype 3 & Clinical isolate & Nasal microcomedone \\
\hline $\begin{array}{l}\text { HL013PA1; } \\
\text { HM-497; EU-09 }\end{array}$ & - & Clinical isolate & - \\
\hline $\begin{array}{l}\text { HL030PA1; } \\
\text { HM-504; EU-16 }\end{array}$ & - & Clinical isolate & - \\
\hline
\end{tabular}

Clinical isolates B104.1 to B104.8 were obtained from Dr. Laura Marinelli (Marinelli et al., 2012). Clinical isolates EU-09 and EU-16 were obtained through BEI Resources, NIAID, NIH as part of the Human Microbiome Project.

- indicates unknown information from the strain providers. of the extract color (Quave et al., 2008). The $\mathrm{IC}_{50}$ and MIC are the minimal concentrations to inhibit at least $50 \%$ and $90 \%$ of the growth, respectively.

\section{Biofilm Eradication}

Liquid cultures were standardized to an optical density at $590 \mathrm{~nm}$ $\left(\mathrm{OD}_{590 \mathrm{~nm}}\right)$ of 0.05 , which corresponds to $5 \times 10^{7} \mathrm{CFU} \mathrm{ml} \mathrm{m}^{-1}$, and pipetted into a 96-well tissue culture plate (TPP92097). After a 24 -h incubation period at $37^{\circ} \mathrm{C}$ in an anaerobic chamber, the media was gently removed using a single-channel micropipette without disturbing the biofilm. Fresh BHId and treatment was added to each well. The plate was incubated for an additional $24 \mathrm{~h}$ at $37^{\circ} \mathrm{C}$ in an anaerobe chamber. The media was gently removed before fixing the biofilms in two steps: adding $100 \%$ ethanol to each well, removing it, and then heat fixing at $60^{\circ} \mathrm{C}$ for $60 \mathrm{~min}$. Crystal violet was then added to each well for $5 \mathrm{~min}$ to stain the biofilms and was subsequently gently rinsed out under tap water. Plates were dried overnight, then a solution of $2.5 \%$ Tween 80 in ethanol was added to elute the stain for $15 \mathrm{~min}$, the eluent transferred to a new 96-well plate, and an $\mathrm{OD}_{595 \mathrm{~nm}}$ obtained to determine total biofilm mass in each well. The minimal biofilm eradication concentration $\left(\mathrm{MBEC}_{50}\right)$ was defined as the minimal concentration of extract required to eradicate at least $50 \%$ of the preformed biofilm.

\section{Mammalian Cytotoxicity Assay}

Mammalian cytotoxicity of extracts was assessed using human keratinocytes (HaCaTs) and a lactate dehydrogenase (LDH) test kit (G-Biosciences, St. Louis, MO) as previously described (Quave et al., 2015). Extracts were sterile-filtered with $0.2-\mu \mathrm{m}$ 
syringe filters and tested at a concentration range of $2-1024 \mu \mathrm{g}$ $\mathrm{ml}^{-1}$. Percent DMSO $(v / v)$ in the wells was $<2 \%$ for all tests.

\section{Chemical Characterization \\ LC-FTMS Analysis}

Liquid chromatography-Fourier transform mass spectrometry (LC-FTMS) was performed on 649C fractions using a Shimadzu SIL-ACHT (Columbia, MD) and Dionex (San Jose, CA) 3600SD HPLC pump. The stationary phase was a Phenomenex Kinetex C18 150 . $2.1 \mathrm{~mm}, 2.5 \mu \mathrm{m}$ with guard column at room temperature. Mobile phases were Optima LC/MS (Fisher Scientific, Waltham, MA) consisting of (A) $0.1 \%$ formic acid in water $(B)$ and $0.1 \%$ formic acid in methanol at a flow rate of 0.15 $\mathrm{ml} / \mathrm{min}$. The gradient profile consisted of initial conditions of 70:30 A/B which was held until $2.6 \mathrm{~min}$., then a linear gradient applied until 5:95 A/B was reached at $52.7 \mathrm{~min}$-this was held until $61.6 \mathrm{~min}$ - then a step gradient applied to $0: 100 \mathrm{~A} / \mathrm{B}$, which was held until $70.4 \mathrm{~min}$, and then the column returned to initial conditions prior to the next injection. A 20- $\mu$ linjection of each fraction was applied onto the column. The chromatography was monitored at 190-600 nm by a Dionex DAD detector. The MS data was acquired in $\mathrm{MS}^{1}$ mode scanning a $\mathrm{m} / z$ of $150-1,500$ on a Thermo Scientific LTQ-FT Ultra MS in positive ESI mode and processed with Thermo Scientific Xcalibur 2.2 SP1.48 software (San Jose, CA). The capillary temperature was $275.0^{\circ} \mathrm{C}$, sheath gas of 40 , source voltage and current of $5.0 \mathrm{kV}$ and $100.0 \mu \mathrm{A}$, and capillary voltage of $29.0 \mathrm{~V}$.

Putative formulas and compounds were determined for peaks of the bioactive fractions of $649 \mathrm{C}$ with greater than $1 \%$ relative abundance by area in the MS total ion chromatograph (TIC). Scifinder (Chemical Abstracts Service) was searched in July 2019 to identify putative matches. The $(M+1)^{+}$from the MS data was used to calculate the accurate mass of the parent ion and the databases searched for small molecules from the genus Callicarpa within $\pm 1.0 \mathrm{Da}$. The molecular formulas of the hits were compared to empirical formulas derived from the experimental MS data. Database hits that matched the experimentally calculated empirical formula, $\pm 10 \mathrm{ppm}$, were evaluated further. Publications on the remaining small molecules were reviewed and the presence of the compound in the genus was verified. The resulting putative compound matches are in Table 5. Only an empirical formula is reported for ions that do not have a match in the database.

\section{RESULTS}

\section{Growth Inhibitory Activity Against $P$. acnes}

Growth inhibitory effects of the crude extract and partitions of C. americana leaves were determined using a static MIC assay. The initial screen was performed on ATCC6919 and demonstrated that the ethyl acetate partition (649C) was the most effective inhibitor of $C$. acnes growth with an $\mathrm{IC}_{50}$ value of $32 \mu \mathrm{g} \mathrm{ml}^{-1}$. 649C was subjected to flash chromatography to yield 31 fractions. Eight out of the 31 fractions exhibited 100\% growth inhibition at $64 \mu \mathrm{g} \mathrm{ml}^{-1}$ against ATCC6919 (Figure 3). Dose-dependent growth inhibition of the most active fractions was then conducted on ATCC6919 as well as nine other clinical isolates of $C$. acnes (Figures 4 and 5). Growth inhibitory activity was observed for each of the 10 isolates of $C$. acnes tested. The most active fractions were $649 \mathrm{C}-\mathrm{F} 9$ and $649 \mathrm{C}-\mathrm{F} 13$, with $\mathrm{IC}_{50}$ values ranging from 4 to $32 \mu \mathrm{g} \mathrm{ml}^{-1}$ and MIC values ranging from 16 to $32 \mu \mathrm{g} \mathrm{ml}_{-}{ }^{1}$ across all isolates (Table 4 and Figure 6). Although no interpretive standards from the CLSI for antibiotic resistance exist for $C$. acnes, it is noteworthy that seven of the nine clinical isolates tested exhibited MICs $>4 \mu \mathrm{g} \mathrm{ml}^{-1}$ for the antibiotic control (clindamycin), which is commonly used in both oral and topical therapies for the management of acne vulgaris. Furthermore, six of the nine clinical isolates tested did not achieve even $50 \%$ growth inhibition at the maximum concentration of clindamycin tested $\left(4 \mu \mathrm{g} \mathrm{ml}^{-1}\right)$.

\section{Biofilm Eradication Activity in C. acnes}

Biofilm eradication activity was assessed, and none of the fractions were found to significantly eradicate the biofilm. A decrease in $30-40 \%$ of biofilm was observed for the highest concentration tested $\left(394 \mu \mathrm{g} \mathrm{ml}^{-1}\right)$. Resveratrol, a previously reported candidate for C. acnes biofilm eradication, reached $30 \%$ eradication at a concentration of $394 \mu \mathrm{g} \mathrm{ml}^{-1}$.

\section{C. americana Extracts Exhibit Low Toxicity to Human Keratinocytes}

To examine possible cytotoxic effects of the extracts in mammalian cells, HaCaT cells were treated at concentrations ranging from 2 to $1,024 \mu \mathrm{g} \mathrm{ml}{ }^{-1}$. For all tested fractions, cytotoxicity $\left(\mathrm{IC}_{50}\right)$ was only observed at more than eight times the dose required for inhibitory activity when compared to the $\mathrm{IC}_{50}$ values for $C$. acnes strain ATCC6919 (Table 4). Fractions 649C-F8 and 649CF9 were the most cytotoxic to the HaCaTs, with $\mathrm{IC}_{50}$ values at 28 and $256 \mu \mathrm{g} \mathrm{ml}^{-1}$, respectively. The therapeutic index (TI) was calculated by dividing the $\mathrm{IC}_{50}$ for mammalian cytotoxicity by the $\mathrm{IC}_{50}$ for $C$. acnes growth inhibition, and the TI range for each fraction is reported in Table 4.

\section{Chemical Characterization of Extracts}

The LC-FTMS ESI-positive mass spectral chromatograms of the ethyl acetate partition (649C) and the bioactive fractions (649C-F9 and 649C-F13) are shown in Figure 7. The ions with greater than a $1 \%$ abundance in the LC-FTMS ESI-positive mode analysis are tabulated in Table 5. Fraction 649C-F9 is the least complex fraction, with over $56 \%$ consisting of a compound with $\mathrm{m} / z 637.4457$ eluting at $51.3 \mathrm{~min}$. A total of nine ions were identified as having greater than $1 \%$ relative abundance. Putative matches were only obtained for peak number 1 with an empirical formula of $\mathrm{C}_{20} \mathrm{H}_{29} \mathrm{O}_{3}$, which corresponded to 14 compounds in Scifinder: $16 \xi$-hydroxycleroda-3,11(E),13-trien-15,16-olide (CAS \#935527-99-4), seco-hinokiol (834870-61-0), angustanoic acid F (104998-60-9), 7-hydroxydehydroabietic acid (9541624-3), 11-hydroxylsugiol (88664-08-8), 3,4-dihydroxyphenethyl glucoside (76873-99-9), 7a-hydroxydehydroabietic acid (7623598-8), 7 $\beta$-hydroxydehydroabietic acid (73609-55-9), 15- hydroxy dehydroabietic acid (54113-95-0), maingayic acid (34327-14-5), 11-hydroxy-13-(1-hydroxy-1- methylethyl)-podocarpa-8,11,13trien-7-one (16755-58-1), 11-hydroxy-12-methoxyabietatriene 


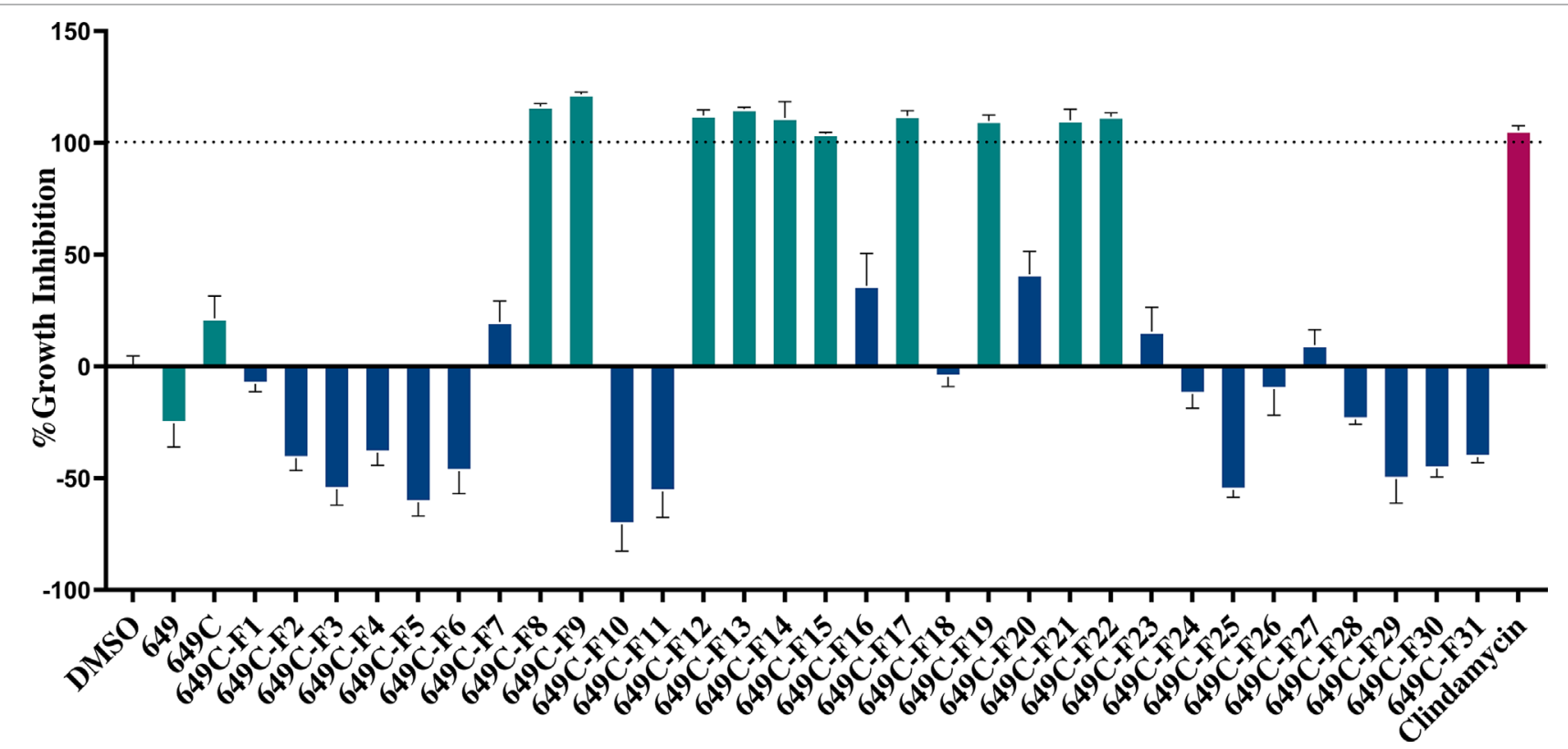

FIGURE 3 | Fractions of $649 \mathrm{C}$ were screened at $64 \mathrm{\mu g} \mathrm{ml}^{-1}$ to determine which ones exhibited the most growth inhibitory activity against $C$. acnes strain ATCC6919. Fractions exhibiting $>90 \%$ growth inhibition and the parent extracts 649 and $649 \mathrm{C}$ (green bars) were further tested for growth inhibition dose-response assay, biofilm eradication, and cytotoxicity against human skin cells. The blue bars represent the least active fractions. Clindamycin was used as a positive antibiotic control (pink bar).
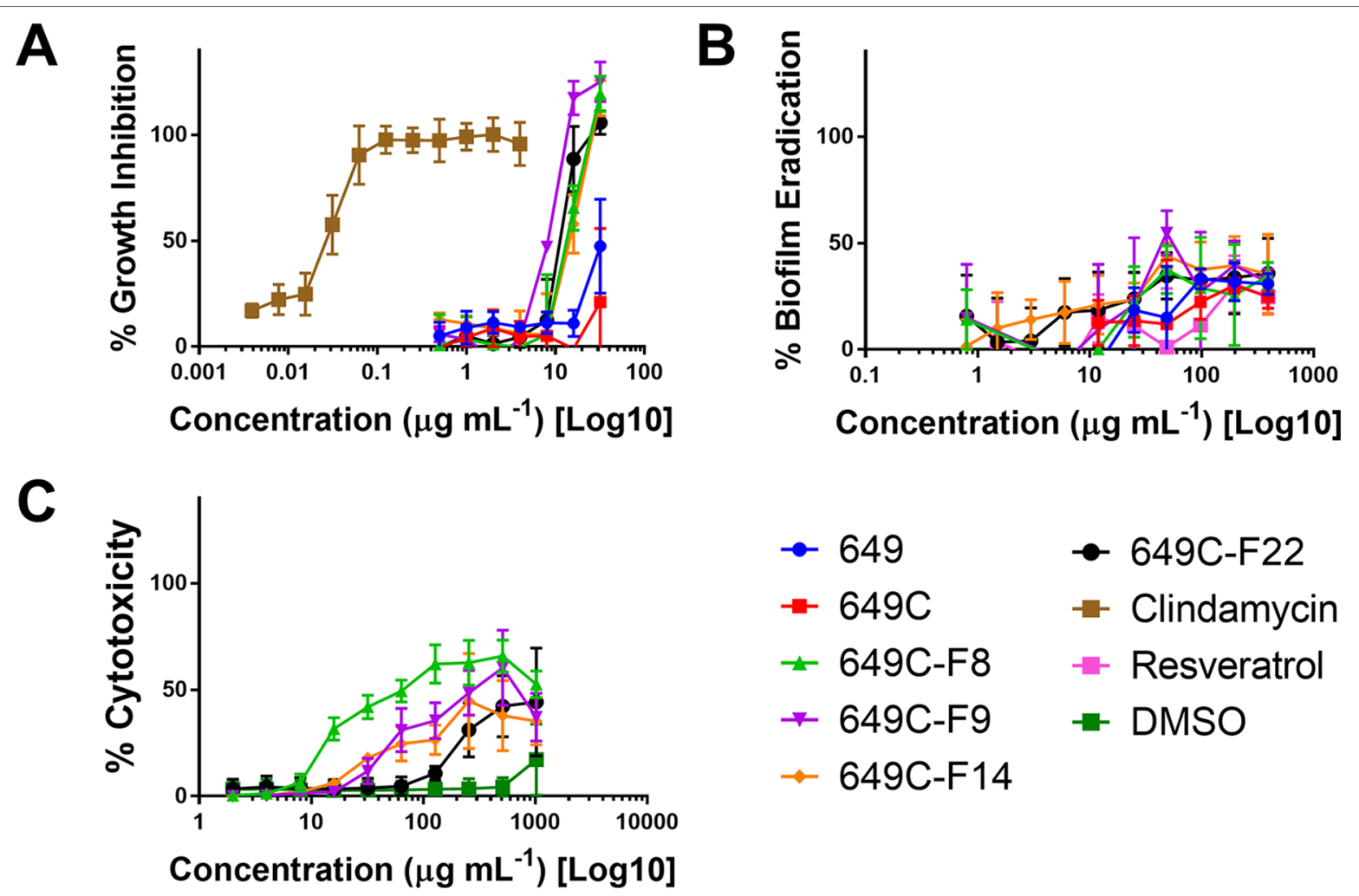

$\rightarrow 649$

$-649 \mathrm{C}$

$+649 \mathrm{C}-\mathrm{F} 8$

$+649 \mathrm{C}-\mathrm{F} 9$

$\rightarrow$ 649C-F14

FIGURE 4 | (A) Growth inhibitory activity, (B) biofilm eradication, and (C) cytotoxicity on human keratinocytes (HaCaTs) of C. americana crude extract and the most active fractions. Tested fraction concentrations ranged from 0.25 to $64 \mu \mathrm{g} \mathrm{ml}^{-1}$, from 0.5 to $394 \mu \mathrm{g} \mathrm{ml}^{-1}$, and from 2 to $1,024 \mu \mathrm{g} \mathrm{ml} \mathrm{f}^{-1}$ for growth inhibition, biofilm eradication, and cytotoxicity assays, respectively. Points represent means and bars are standard error of the mean. Dotted lines represent $50 \%$ and $90 \%$ thresholds. 

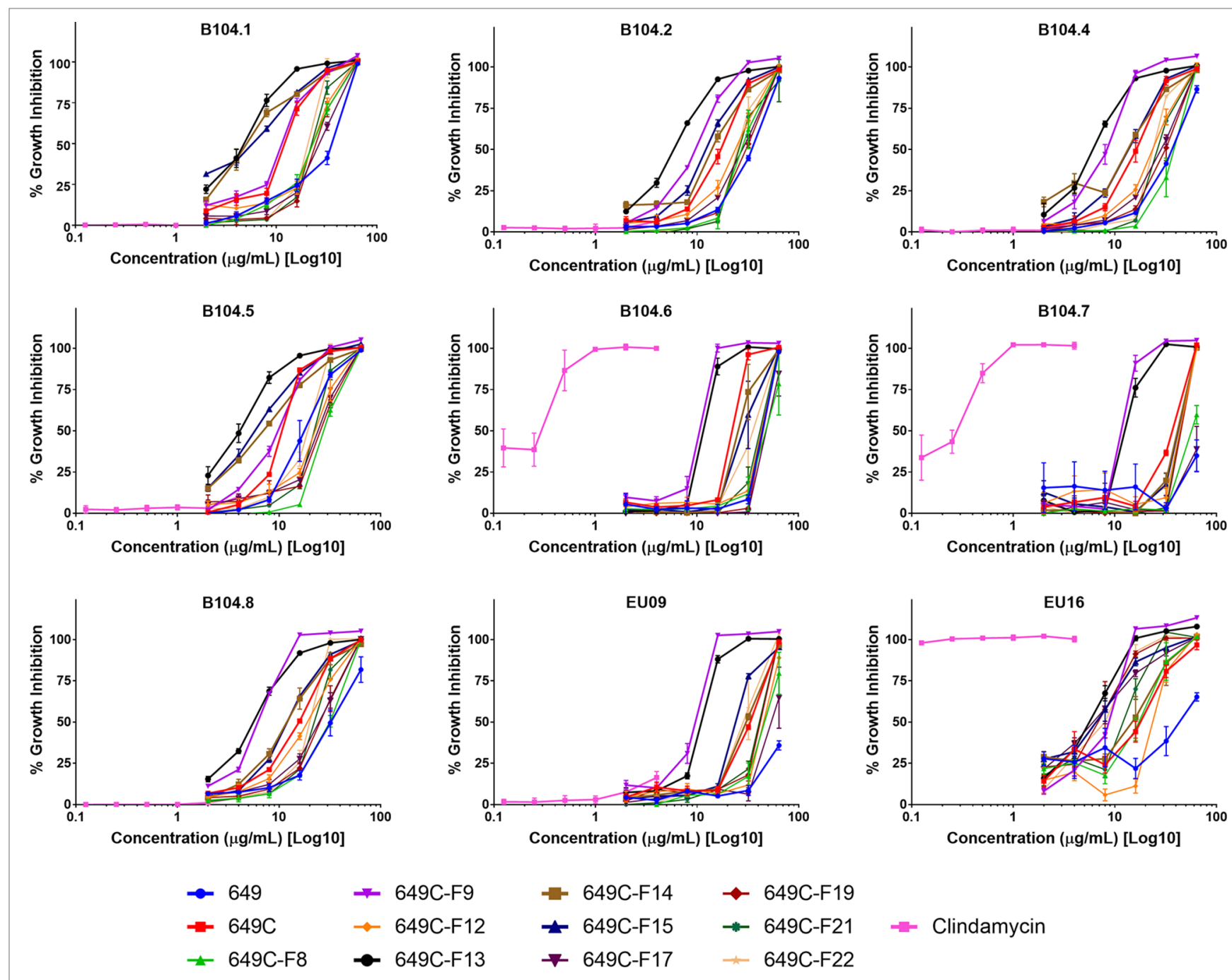

FIGURE 5 | Growth inhibitory activity of extracts and fractions against a panel of nine clinical isolates of $C$. acnes.

(16755-54-7), methyltrans-communate(15798-13-7), andmethyl isopimarate (1686-62-0).

Fraction 649-F13 was more diverse, with 19 ions having greater than $1 \%$ relative abundance by LC-MS analysis. As before, a single ion dominates, $m / z 669.4379$ eluting at $49.6 \mathrm{~min}$. There are no putative matches for this ion in Scifinder. However, putative matches were obtained for five other ions from 649C-F13, identified as peaks 2-6 in Figure 7. Peak 2 has $m / z 376.2583$ and empirical formula $\mathrm{C}_{23} \mathrm{H}_{36} \mathrm{O}_{4}$ and corresponds to [5'aS-(5'aa,7' aa, $\left.9^{\prime} a, 10^{\prime} \alpha, 12^{\prime} \mathrm{a} a, 12^{\prime} \mathrm{b} \beta\right)$ ]-decahydro-2,2,5',5',12'b-pentamethylspiro [1,3-dioxolane-4,9' $\left(8^{\prime} \mathrm{H}\right)$ - [7a, 10] methano $[7 \mathrm{aH}]$ cyclohepta[g][2]benzoxepin]-3'(2'H)-one (CAS \#49817-39- 2). Peak 3 has $m / z \quad 301.2152$ and empirical formula $\mathrm{C}_{20} \mathrm{H}_{29} \mathrm{O}_{2}$ which corresponds to $(5 \alpha, 9 \alpha, 10 \beta)$-3-oxo-kaur-15-en-17-al (CAS \#878000-26-1), 18-oxoferruginol (108904-92-3), 4-epidehydroabietic acid (5155-70-4), and dehydroabietic acid (1740-19-8). Peak 4 has $m / z \quad 303.2309$ and empirical formula $\mathrm{C}_{20} \mathrm{H}_{31} \mathrm{O}_{2}$ and corresponds to callicarpic acid A (CAS
\#1130124-82-1), 1-[2-(3-furanyl)ethyl]-1,3,4,7,8,8a-hexahydro1,2,5-trimethyl-4a(2H)-naphthalenemethanol (35319-12-1), isopimaric acid (5835-26-7), and cryptopimaric acid (471-749). Peak 5 has $m / z 305.2464$ and empirical formula $\mathrm{C}_{20} \mathrm{H}_{33} \mathrm{O}_{2}$ which corresponds to $[4 a S-(4 a a, 4 b \beta, 8 a a, 10 a \beta)]-4 a, 4 b, 5,6,7,8,8 a$, 9,10,10a-decahydro-2-(1-hydroxy-1-methylethyl)-4b,8,8trimethyl-4(1H)-phenanthrenone (CAS \#121926-95-2), [1R-(1 $\alpha$, $4 \mathrm{a} \beta, 4 \mathrm{~b} a, 7 \mathrm{a}, 8 \mathrm{a}, 10 \mathrm{a} \alpha)$ ] - 7-ethenyl-1,2,3,4,4a,4b, 5, 6, 7, 8, 10, 10 a-dodecahydro- 8 - hydroxy-1,4a, 7 - trimet hyl-1phenanthrenemethanol (101467-73-6), 15,16-dihydroisopima ric acid (5673-36-9), 15,16-dihydrosandaracopimaric acid (4807-69-6), and arachidonic acid (506-32-1). Peak 6 has $m / z$ 319.2257 and empirical formula $\mathrm{C}_{20} \mathrm{H}_{31} \mathrm{O}_{3}$ and corresponds to 4-[2-[(1S,4aR,6S,8aR)-1,4,4a,5,6,7,8,8a-octahydro-6-hydroxy2,5,5,8a-tetramethyl-1-naphthalenyl] ethyl]-2(5H)-furanone (CAS \#2305691-63-6),4-[2-[(1S,4aR,6S,8aR)-decahydro-6-hydroxy-5,5, 8 a-trimethyl-2-methylene-1-naphthalenyl] ethyl]-2(5H)furanone (2305691-62-5), nudiflopene B (2226250-84-4), (1S, 
TABLE 4 | C. americana extract, partition, and fraction growth inhibition $\left(\mathrm{IC}_{50}\right.$ and $\left.\mathrm{MIC}\right)$ and HaCat cytotoxicity $I \mathrm{C}_{50} \mathrm{values}$ (in $\left.\mu \mathrm{g} \mathrm{ml}^{-1}\right)$.

\begin{tabular}{|c|c|c|c|c|c|c|c|c|c|c|c|c|c|c|}
\hline & & 649 & $649 C$ & $\begin{array}{c}\text { 649C- } \\
\text { F8 }\end{array}$ & $\begin{array}{c}\text { 649C- } \\
\text { F9 }\end{array}$ & $\begin{array}{c}\text { 649C- } \\
\text { F12 }\end{array}$ & $\begin{array}{c}\text { 649C- } \\
\text { F13 }\end{array}$ & $\begin{array}{c}\text { 649C- } \\
\text { F14 }\end{array}$ & $\begin{array}{c}\text { 649C- } \\
\text { F15 }\end{array}$ & $\begin{array}{c}\text { 649C- } \\
\text { F17 }\end{array}$ & $\begin{array}{c}\text { 649C- } \\
\text { F19 }\end{array}$ & $\begin{array}{c}\text { 649C- } \\
\text { F21 }\end{array}$ & $\begin{array}{c}\text { 649C- } \\
\text { F22 }\end{array}$ & Cli- \\
\hline \multirow{10}{*}{$\begin{array}{l}\mathrm{IC}_{50} \text { for } \mathrm{C} . \\
\text { acnes } \\
\text { growth }\end{array}$} & ATCC6919 & 32 & 32 & 16 & 8 & 16 & 16 & 16 & 16 & 16 & 16 & 16 & 16 & 0.0625 \\
\hline & B104.1 & 64 & 16 & 32 & 16 & 32 & 8 & 8 & 8 & 32 & 32 & 32 & 32 & $>4$ \\
\hline & B104.2 & 64 & 32 & 32 & 32 & 32 & 8 & 16 & 16 & 32 & 32 & 32 & 32 & $>4$ \\
\hline & B104.4 & 64 & 16 & 64 & 8 & 32 & 8 & 16 & 16 & 32 & 32 & 32 & 32 & $>4$ \\
\hline & B104.5 & 32 & 16 & 32 & 16 & 32 & 4 & 8 & 8 & 32 & 32 & 32 & 32 & $>4$ \\
\hline & B104.6 & 64 & 32 & 64 & 16 & 64 & 16 & 32 & 32 & 64 & 64 & 64 & 64 & 0.5 \\
\hline & B104.7 & $>64$ & 64 & 64 & 16 & 64 & 16 & 64 & 64 & $>64$ & 64 & 64 & 64 & 0.5 \\
\hline & B104.8 & 64 & 16 & 32 & 8 & 32 & 8 & 16 & 16 & 32 & 32 & 32 & 32 & $>4$ \\
\hline & EU-09 & $>64$ & 32 & 64 & 16 & 64 & 16 & 32 & 32 & 64 & 64 & 64 & 32 & $>4$ \\
\hline & EU-16 & 64 & 32 & 32 & 16 & 32 & 8 & 16 & 8 & 8 & 8 & 16 & 16 & $\begin{array}{c}< \\
0.125\end{array}$ \\
\hline MIC for & ATCC6919 & $>32$ & $>32$ & 32 & 16 & 16 & 16 & 32 & 32 & 16 & 16 & 16 & 16 & $>8$ \\
\hline C. acnes & B104.1 & 64 & 32 & 64 & 32 & 64 & 16 & 32 & 32 & 64 & 64 & 64 & 64 & $>4$ \\
\hline \multirow[t]{8}{*}{ growth } & B104.2 & 64 & 32 & 64 & 32 & 64 & 16 & 64 & 32 & 64 & 64 & 64 & 64 & $>4$ \\
\hline & B104.4 & 64 & 32 & 64 & 16 & 64 & 16 & 64 & 32 & 64 & 64 & 64 & 64 & $>4$ \\
\hline & B104.5 & 64 & 32 & 64 & 32 & 64 & 16 & 32 & 32 & 64 & 64 & 64 & 32 & $>4$ \\
\hline & B104.6 & 64 & 32 & $>64$ & 16 & 64 & 16 & 64 & 64 & $>64$ & 64 & 64 & 64 & 0.5 \\
\hline & B104.7 & $>64$ & 64 & $>64$ & 16 & 64 & 32 & 64 & 64 & $>64$ & 64 & 64 & 64 & 1 \\
\hline & B104.8 & $>64$ & 32 & 64 & 16 & 64 & 16 & 32 & 32 & 64 & 64 & 64 & 32 & $>4$ \\
\hline & EU-09 & $>64$ & 64 & $>64$ & 16 & 64 & 16 & 64 & 64 & $>64$ & 64 & 64 & 64 & $>4$ \\
\hline & EU-16 & $>64$ & 64 & 32 & 16 & 64 & 16 & 64 & 32 & 32 & 16 & 32 & 16 & 0.125 \\
\hline \multirow[t]{2}{*}{ HaCat } & $I C_{50}$ & $>$ & $>$ & 128 & 256 & $>512$ & $>512$ & $>$ & $>$ & 512 & $>512$ & $>512$ & 1024 & - \\
\hline & & 1024 & 1024 & & & & & 1024 & 512 & & & & & \\
\hline \multirow[t]{2}{*}{ TI } & $\begin{array}{l}\text { Lower } \\
\text { range }\end{array}$ & 16 & 32 & 2 & 8 & 8 & 32 & 16 & 8 & 8 & 8 & 8 & 16 & - \\
\hline & $\begin{array}{l}\text { Upper } \\
\text { range }\end{array}$ & $>32$ & $>64$ & 8 & 32 & 32 & 128 & 128 & 64 & 64 & 64 & 32 & 64 & - \\
\hline
\end{tabular}

All values were determined as compared to the vehicle control for at least three replicates. The therapeutic index (TI) is reported as a range of values for the $10 \mathrm{C}$. acnes isolates (cytotoxicity $I C_{50}$ divided by growth inhibition $I C_{50}$ ).

Cli clindamycin, antibiotic control.

4aS, 4bS, 7S, 8S, 10aS)-7-ethenyl-1, 2, 3, 4, 4a, 4b , 5, 6, 7, 8, 10, 10a -dodecahydro-8-hydroxy-1,4a,7-trimethyl-1-phenanthreneca rboxylic acid (2137490-87-8), callilongisin D (1367097-06-0), callilongisin C (1367097-03-7), callilongisin B (1367097-00 -4), (1S,2S,8aS)-1,2,3,7,8,8a-hexahydro-8a-hydroxy-1-methyl -2-(1-methylethenyl)-6-(1-methylethyl)-1-naphthalenepro panoic acid (1123207-97-5), 12(S)-hydroxycleroda-3, 13-dien16, 15-olide (935293-68-8), 12(S)-hydroxycleroda-3, 13-dien-15,16-olide (935293-66-6), 16\%-hydroxycleroda-3,13dien-15,16-olide (141979-19-3), 7a-hydroxysandaracopimaric $\operatorname{acid}(122537-68-2)$, [4aS-(4aa,7aa,8a, $9 \mathrm{~b} \beta)]-2,3,4,4 \mathrm{a}, 5,6,7,7 \mathrm{a}, 8 \mathrm{a}$, 9b-decahydro-7a-(1-hydroxy-1-methylethyl)-4,4,9b-trimethylphenanthro[2,3-b] oxiren-9(1H)-one (121926-98-5), calliphyllin (101467-72-5), and 3-oxoanticopalic acid (83997-21-1).

\section{DISCUSSION}

The most active fractions of the C. americana leaf extracts exhibited MICs against $C$. acnes isolates at concentrations as low as 0.016 $\mathrm{mg} \mathrm{ml}^{-1}$, which is 30 times less than the lowest MIC value found for other botanical extracts previously investigated, including Jeju (Thymus quinquecostatus Celak., Lamiaceae-MIC of $0.5 \mathrm{mg} \mathrm{ml}^{-1}$ ), Damask Rose (Rosa x damascene Herrm., Rosaceae-MIC of $2 \mathrm{mg}$ $\mathrm{ml}^{-1}$ ), Duzhong (Eucommia ulmoides Oliv., Eucommiaceae-MIC of $0.5 \mathrm{mg} \mathrm{m}^{-1}$ ), and Maté (Ilex paraguariensis A.St.-Hil.-MIC of $1 \mathrm{mg} \mathrm{m}^{-1}$ ) (Oh et al., 2009; Tsai et al., 2010). In comparison to the growth inhibition activity, the C. americana extracts were less effective at the eradication of existing biofilm. Following the result reported by Coenye et al., we included resveratrol as a biofilm eradication control (Coenye et al., 2012). At the highest concentration tested $\left(394 \mu \mathrm{g} \mathrm{ml} \mathrm{m}^{-1}\right.$ ), only $21 \%$ inhibition was achieved by resveratrol. However, the previous $80 \%$ biofilm eradication reported for resveratrol was at a concentration of 3,200 $\mu \mathrm{g} \mathrm{ml} \mathrm{m}^{-1}$.

The cytotoxicity $\left(\mathrm{IC}_{50}\right)$ of the most active fractions, 649CF9 and 649C-F13, were at concentrations 32 and $>128$ times greater than that required for $C$. acnes growth inhibition $\left(\mathrm{IC}_{50}\right)$. These results demonstrate the strong potential of $C$. americana fractions to reduce $C$. acnes fitness at a good therapeutic index ratio of mammalian toxicity to antimicrobial activity.

In other studies, bioassay-guided fractionation of the dried leaf, twigs, and fruits of C. americana extracts led to the isolation of six clerodane diterpenes (Jones et al., 2007). Flavonoids including genkwanin, 5-hydroxy-7,4'-dimethoxyflavone, and luteolin were also found in these extracts. The leaf essential oil contained lipids [(E)-2-hexenal and 1-octen-3-ol] as well as monoterpenoids (nopinone, $\alpha$-pinene, and $\beta$-pinene), sesquiterpenoids ( $\alpha$-cadinol, caryophyllene oxide, 7-epi- $\alpha$-eudesmol, $\alpha$-humulene, humulene epoxide II, intermediol, khusinol, valencene, $a$-selinene, and 

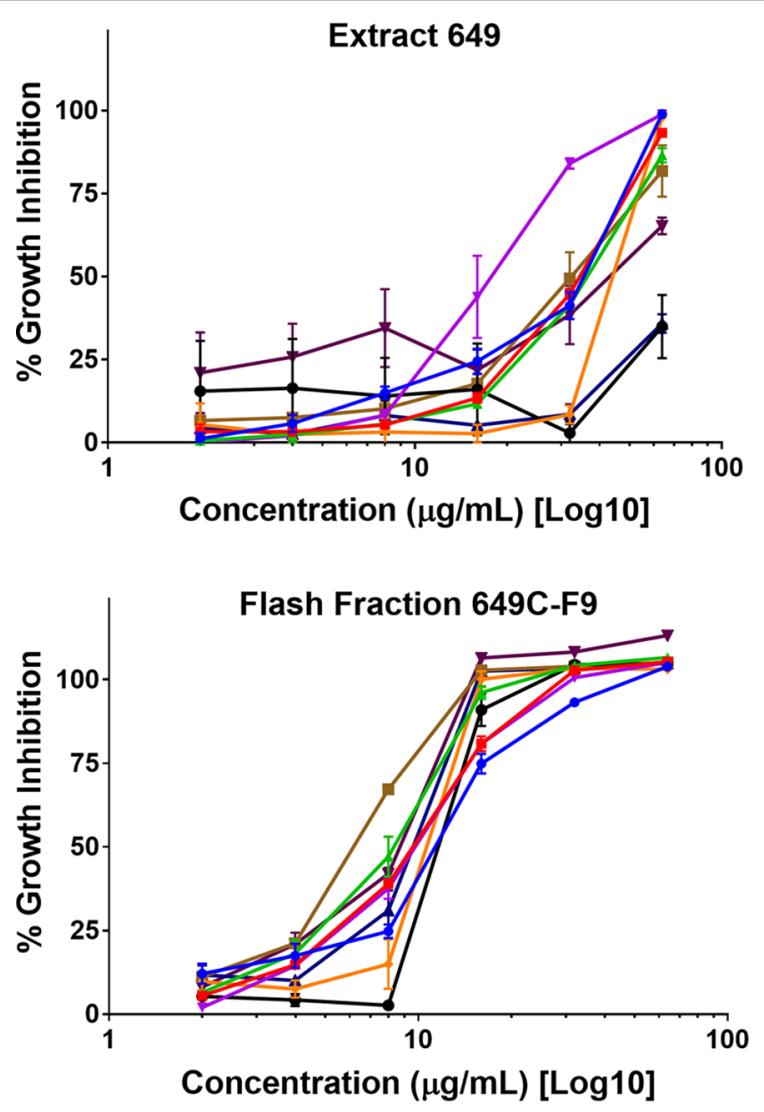

$\begin{array}{ll}\rightarrow \mathrm{B} 104.1 & \neq \mathrm{B} 104.4 \\ -\mathrm{B} 104.2 & \neq \mathrm{B} 104.5\end{array}$

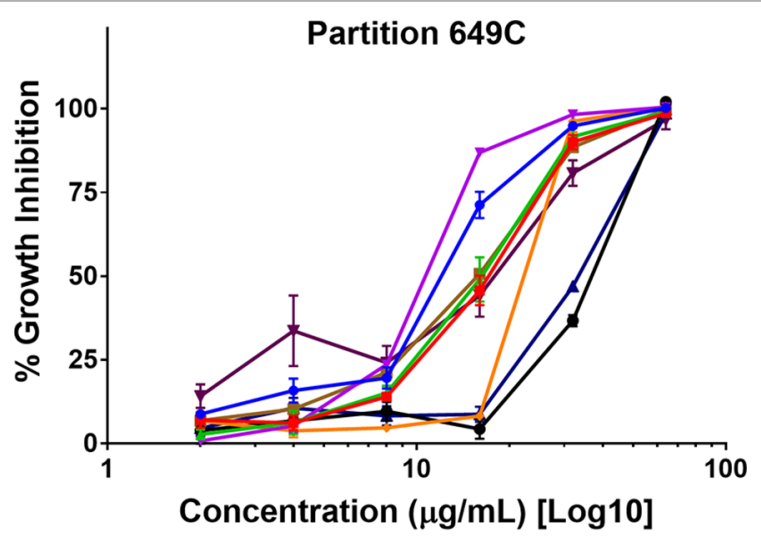

Flash Fraction 649C-F13
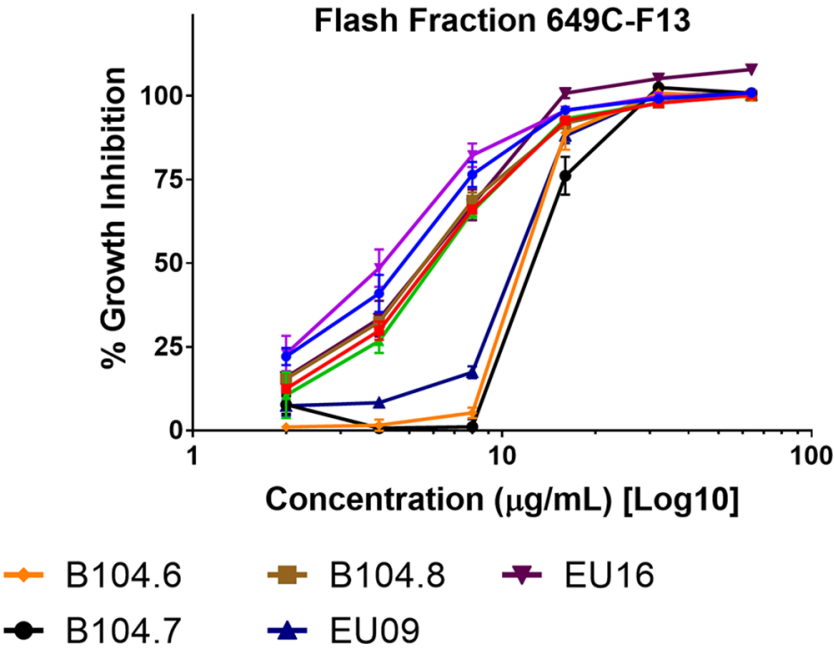

FIGURE 6 | Growth inhibitory activity of the most active fractions and their parent extracts against a panel of nine clinical isolates of $C$. acnes.

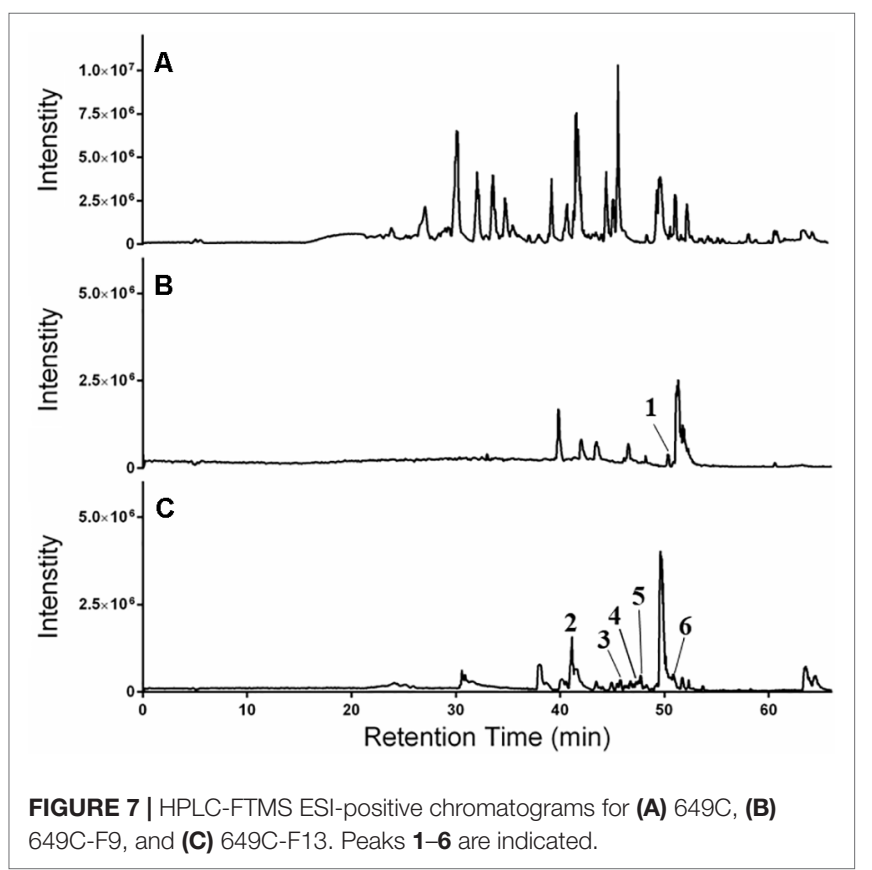

7-epi-a-selinene), and triperpenoids (euscaphic acid) (Tellez et al., 2000; Kobaisy et al., 2002; Cantrell et al., 2005; Jones et al., 2007). Some compounds were active against human cancer cell lines with a cytotoxic activity below $5 \mu \mathrm{g} \mathrm{ml}^{-1}$. These include $12(\mathrm{~S}), 16$ dihydroxycleroda-3,13-dien-15,16-olide, 2-formyl-16hydroxy-3-a-norcleroda-2,13-dien-15,16-olide, genkwanin, 12(S)-hydroxycleroda-3,13-dien-16,15-olide, 16-hy droxycleroda-3,13-dien-15,16-olide, and 16-hydroxy-cleroda3,11(E),13-trien-15,16-olide. Intermedeol and callicarpenal were demonstrated to be effective deterrents of $A$. stephensi and $A$. aegypti mosquitos, and clerodane diterpenes are also known to have insect antifeedant properties (Gebbinck et al., 2002). To the best of the authors' knowledge, this is the first report on the antibacterial activity of C. americana extracts against $C$. acnes.

By colonizing the pilosebaceous follicle and inducing the production of reactive oxygen species highly toxic to the cells (Shalita et al., 2011), C. acnes exacerbates the inflammation associated with acne vulgaris. C. acnes also worsens the symptoms by inducing immune cells to produce pro-inflammatory cytokines including interleukins and tumor necrosis factors (Vowels et al., 1995). Prior studies on 
TABLE 5 | Tabulated $(\mathrm{M}+\mathrm{H})^{+}$ions, empirical formulas, for the bioactive $649 \mathrm{C}$ fractions.

\begin{tabular}{|c|c|c|c|c|}
\hline Peak number & Retention time (min) & $m / z$ & Relative abundance (\%) & Empirical formula $\Delta$ (ppm) \\
\hline & 33 & 371.0991 & 1.4 & $\mathrm{C}_{16} \mathrm{H}_{19} \mathrm{O}_{10}(4.7)$ \\
\hline & 43.4 & 368.2426 & 8.19 & $\mathrm{C}_{17} \mathrm{H}_{36} \mathrm{O}_{8}$ (5.9) \\
\hline & 46.5 & 718.449 & 5.73 & $\mathrm{C}_{37} \mathrm{H}_{66} \mathrm{O}_{13}(-1.1)$ \\
\hline & 48.2 & 371.0994 & 0.92 & $\mathrm{C}_{19} \mathrm{H}_{17} \mathrm{O}_{7} \mathrm{~N}(-1.6)$ \\
\hline & 60.6 & 630.504 & 1.24 & $\mathrm{C}_{36} \mathrm{H}_{70} \mathrm{O}_{8}(-4.0)$ \\
\hline \multicolumn{5}{|c|}{ Fraction 649C-F13 } \\
\hline & 24.2 & 608.3806 & 2.09 & $\mathrm{C}_{30} \mathrm{H}_{56} \mathrm{O}_{12}(6.5)$ \\
\hline & 30.6 & 371.0994 & 1.66 & $\mathrm{C}_{16} \mathrm{H}_{19} \mathrm{O}_{10}(5.7)$ \\
\hline & 30.9 & 371.0993 & 1.04 & $\mathrm{C}_{16} \mathrm{H}_{19} \mathrm{O}_{10}$ (5.5) \\
\hline & 38.0 & 384.2368 & 7.89 & $\mathrm{C}_{17} \mathrm{H}_{36} \mathrm{O}_{9}(3.7)$ \\
\hline & 44.9 & 718.4499 & 1.01 & $\mathrm{C}_{37} \mathrm{H}_{66} \mathrm{O}_{13}(-1.5)$ \\
\hline 3 & 45.8 & 301.2152 & 1.48 & $\mathrm{C}_{20} \mathrm{H}_{29} \mathrm{O}_{2}(-3.5)$ \\
\hline 4 & 47.5 & $\begin{array}{c}\mathbf{3 0 3 . 2 3 0 9 ,} 605.4541 \\
750.4388\end{array}$ & 1.52 & $\mathrm{C}_{20} \mathrm{H}_{31} \mathrm{O}_{2}(-3.3)$ \\
\hline \multirow[t]{2}{*}{5} & 47.7 & $\mathbf{3 0 5 . 2 4 6 4 , 6 0 9 . 4 8 5 1}$ & 1.64 & $\mathrm{C}_{20} \mathrm{H}_{33} \mathrm{O}_{2}(-3.5)$ \\
\hline & 49.6 & 669.4379 & 36.27 & $\mathrm{C}_{40} \mathrm{H}_{61} \mathrm{O}_{8}(2.7)$ \\
\hline \multirow[t]{6}{*}{6} & 50.9 & $\mathbf{3 1 9 . 2 2 5 7 , 6 5 9 . 4 2 5 8}$ & 2.03 & $\mathrm{C}_{20} \mathrm{H}_{31} \mathrm{O}_{3}(-3.3)$ \\
\hline & 51.7 & 654.4701 & 1.51 & $\mathrm{C}_{37} \mathrm{H}_{66} \mathrm{O}_{9}(0)$ \\
\hline & 63.5 & 621.302 & 6.87 & $\mathrm{C}_{43} \mathrm{H}_{41} \mathrm{O}_{4}(3.2)$ \\
\hline & 64.5 & 621.3017 & 4.05 & $\mathrm{C}_{43} \mathrm{H}_{41} \mathrm{O}_{4}(2.8)$ \\
\hline & 67.2 & 621.3037 & 2.19 & $\mathrm{C}_{36} \mathrm{H}_{45} \mathrm{O}_{9}(-3.4)$ \\
\hline & 76.3 & 371.0991 & 5.02 & $\mathrm{C}_{16} \mathrm{H}_{19} \mathrm{O}_{10}$ (5.0) \\
\hline
\end{tabular}

ND, formula not determined.

${ }^{*}$ Percent relative abundance is determined by peak area.

the putative formula is reported for bold ion.

ethanolic extracts of rosemary demonstrated a significant reduction of cytokine production in vitro and attenuation of swelling and inflammation in a mouse model (Tsai et al., 2010). The minimum inhibitory concentration was $4 \mathrm{mg}$ $\mathrm{ml}^{-1}$, which is 250 times more than the lowest MIC reported in the present paper. By effectively reducing $C$. acnes growth and proliferation, C. americana leaf extracts may also impact inflammatory processes. Further research is needed to evaluate this aspect of $C$. americana treatments with in vivo infection models.

While treating acne with antibiotics, such as erythromycin and clindamycin, was shown to significantly reduce inflammation, extensive use of oral and/or topical antibiotics since the 1960s has led to the emergence of resistant strains (Eady et al., 1989). This underlines the need for alternative compounds for acne therapy. Other factors such as androgens, poor digestion, or smoking habits (Leyden, 1995) are also important in the development and persistence of the disease. Treatments should focus not only on the consequences but also on the causes of acne and could combine cross-acting compounds to reduce sebum production, correct stomach acidity for better digestion, while also reducing inflammation (Yarnell and Abascal, 2006). Previous studies reported the interesting potential of botanical combinations in treatments to reduce acne (Lalla et al., 2001; K1lıç et al., 2019). Our study highlights the potential of C. americana leaf extracts to efficiently reduce bacterial proliferation and lessen acne vulgaris symptoms.

\section{CONCLUSION}

Our work has demonstrated the promising antibacterial potential of $C$. americana constituents against C. acnes growth. Fractions 649C-F9 and 649C-F13 exhibited growth inhibitory activity against a panel of 10 C. acnes isolates and with a good therapeutic index of 32 and $>128$, respectively). Future studies should pursue isolation and structural determination of active components, further examination of the efficacy and safety of the compounds, and examine the mechanism of action for these observed antibacterial effects.

\section{DATA AVAILABILITY STATEMENT}

The raw data supporting the conclusions of this manuscript will be made available by the authors, without undue reservation, to any qualified researcher. 


\section{AUTHOR CONTRIBUTIONS}

RP prepared the extracts and fractions and performed HaCaT cytotoxicity experiments. RP and $\mathrm{SH}$ performed antibacterial assays. JL performed the chemical analysis of the extracts. CQ designed and directed the study. RP and CQ analyzed the data and wrote the manuscript. All authors read, revised, and approved the final manuscript.

\section{FUNDING}

This work was supported by faculty development funds from the Emory University School of Medicine, Department of

\section{REFERENCES}

Bhambri, S., Del Rosso, J. Q., and Bhambri, A. (2009). Pathogenesis of acne vulgaris: recent advances. J. Drugs Dermatol. 8, 615-618.

Bhat, P., Hegde, G. R., Hegde, G., and Mulgund, G. S. (2014). Ethnomedicinal plants to cure skin diseases - an account of the traditional knowledge in the coastal parts of Central Western Ghats, Karnataka, India. J. Ethnopharmacol. 151, 493-502. doi: 10.1016/j.jep.2013.10.062

Cantrell, C. L., Klun, J. A., Bryson, C. T., Kobaisy, M., and Duke, S. O. (2005). Isolation and identification of mosquito bite deterrent terpenoids from leaves of American (Callicarpa americana) and Japanese (Callicarpa japonica) Beautyberry. J. Agric. Food Chem. 53, 5948-5953. doi: 10.1021/jf0509308

Coenye, T., Brackman, G., Rigole, P., De Witte, E., Honraet, K., Rossel, B., et al. (2012). Eradication of Propionibacterium acnes biofilms by plant extracts and putative identification of icariin, resveratrol and salidroside as active compounds. Phytomedicine 19, 409-412. doi: 10.1016/j.phymed.2011.10.005

Cox, P. A. (1994). "The ethnobotanical approach to drug discovery: strengths and limitations," in Ethnobotany and the search for new drugs (Chichester: Wiley).

Eady, E. A., Cove, J., Holland, K., and Cunliffe, W. (1989). Erythromycin resistant propionibacteria in antibiotic treated acne patients: association with therapeutic failure. Br. J. Dermatol. 121, 51-57. doi: 10.1111/j.1365-2133.1989.tb01399.x

Gebbinck, E. A. K., Jansen, B. J., and De Groot, A. (2002). Insect antifeedant activity of clerodane diterpenes and related model compounds. Phytochemistry 61, 737770. doi: 10.1016/S0031-9422(02)00174-7

Gupta, A., Nagariya, A., Mishra, A., Bansal, P., Kumar, S., Gupta, V., et al. (2010). Ethno-potential of medicinal herbs in skin diseases: an overview. J. Pharm. Res. 3, 435-441. doi: 10.1186/s12906-019-2605-6

Jones, W. P., and Kinghorn, A. D. (2008). Biologically active natural products of the genus Callicarpa. Curr. Bioact. Compd. 4, 15-32. doi: $10.2174 / 157340708784533393$

Jones, W. P., Lobo-Echeverri, T., Mi, Q., Chai, H.-B., Soejarto, D. D., Cordell, G. A., et al. (2007). Cytotoxic constituents from the fruiting branches of Callicarpa americana collected in southern Florida. J. Nat. Prod. 70, 372-377. doi: 10.1021/np060534z

Kadereit, J. W. (2004). Flowering Plants. Dicotyledons: Lamiales (except Acanthaceae including Avicenniaceae). Berlin: Springer. doi: 10.1007/978-3-642-18617-2

Kılıç, S., Okullu, S. Ö., Kurt, Ö., Sevinç, H., Dündar, C., Altınordu, F., et al. (2019). Efficacy of two plant extracts against acne vulgaris: initial results of microbiological tests and cell culture studies. J. Cosmet. Dermatol. 18, 10611065. doi: 10.1111/jocd.12814

Kobaisy, M., Tellez, M. R., Dayan, F. E., and Duke, S. O. (2002). Phytotoxicity and volatile constituents from leaves of Callicarpa japonica Thunb. Phytochemistry 61, 37-40. doi: 10.1016/S0031-9422(02)00207-8

Lalla, J., Nandedkar, S., Paranjape, M., and Talreja, N. (2001). Clinical trials of ayurvedic formulations in the treatment of acne vulgaris. J. Ethnopharmacol. 78, 99-102. doi: 10.1016/S0378-8741(01)00323-3

Leyden, J. J. (1995). New understandings of the pathogenesis of acne. J. Am. Acad. Dermatol. 32, S15-S25. doi: 10.1016/0190-9622(95)90416-6
Dermatology and Emory College of Arts and Sciences, Center for the Study of Human Health.

\section{ACKNOWLEDGMENTS}

The following reagent was obtained through BEI Resources, NIAID, NIH as part of the Human Microbiome Project: HL013PA1 and HL030PA1. We thank Dr. Laura Marinelli for the provision of the following clinical isolates: B104.1, B104.2, B104.4, B104.5, B104.6, B104.7, and B104.8. We thank Dr. T. Samarakoon (Emory University Herbarium) for assistance with the collection and identification of the study species, Dr. F. Chassagne for assistance with the cell culture assays, and M. Dettweiler for assistance with the growth inhibition plates setup.

Leyden, J. J., and Del Rosso, J. Q. (2011). Oral antibiotic therapy for acne vulgaris: pharmacokinetic and pharmacodynamic perspectives. J. Clin. Aesthet. Dermatol. 4, 40-47.

Margolis, D. J., Bowe, W. P., Hoffstad, O., and Berlin, J. A. (2005). Antibiotic treatment of acne may be associated with upper respiratory tract infections. Arch. Dermatol. 141, 1132-1136. doi: 10.1001/archderm.141.9.1132

Margolis, D. J., Fanelli, M., Kupperman, E., Papadopoulos, M., Metlay, J. P., Xie, S. X., et al. (2012). Association of pharyngitis with oral antibiotic use for the treatment of acne: a cross-sectional and prospective cohort study. Arch. Dermatol. 148, 326-332. doi: 10.1001/archdermatol.2011.355

Marinelli, L. J., Fitz-Gibbon, S., Hayes, C., Bowman, C., Inkeles, M., Loncaric, A., et al. (2012). Propionibacterium acnes bacteriophages display limited genetic diversity and broad killing activity against bacterial skin isolates. mBio 3, e00279-e00212. doi: 10.1128/mBio.00279-12

Mills, O., Jr., Thornsberry, C., Cardin, C. W., Smiles, K. A., and Leyden, J. J. (2002). Bacterial resistance and therapeutic outcome following three months of topical acne therapy with $2 \%$ erythromycin gel versus its vehicle. Acta. Derm. Venereol. 82, 260-265. doi: 10.1080/000155502320323216

Nelson, K., Lyles, J. T., Li, T., Saitta, A., Addie-Noye, E., Tyler, P., et al. (2016). Anti-acne activity of Italian medicinal plants used for skin infection. Front. Pharmacol. 7, 425-425. doi: 10.3389/fphar.2016.00425

Oh, T.-H., Kim, S.-S., Yoon, W.-J., Kim, J.-Y., Yang, E.-J., Lee, N. H., et al. (2009). Chemical composition and biological activities of Jeju Thymus quinquecostatus essential oils against Propionibacterium species inducing acne. J. Gen. Appl. Microbiol. 55, 63-68. doi: 10.2323/jgam.55.63

Quave, C. L., Lyles, J. T., Kavanaugh, J. S., Nelson, K., Parlet, C. P., Crosby, H. A., et al. (2015). Castanea sativa (European chestnut) leaf extracts rich in ursene and oleanene derivatives block Staphylococcus aureus virulence and pathogenesis without detectable resistance. PLOS ONE 10, e0136486. doi: 10.1371/journal. pone.0136486

Quave, C. L., Plano, L. R., Pantuso, T., and Bennett, B. C. (2008). Effects of extracts from Italian medicinal plants on planktonic growth, biofilm formation and adherence of methicillin-resistant Staphylococcus aureus. J. Ethnopharmacol. 118, 418-428. doi: 10.1016/j.jep.2008.05.005

Sernec. (2019). Southeast Regional Network of Expertise and Collections [Online]. http:// sernecportal.org/portal/. Available: http://sernecportal.org/portal/ (Accessed May 15 2019).

Shah, R., and Peethambaran, B. (2018). "Chapter 19-Anti-inflammatory and antimicrobial properties of Achillea millefolium in acne treatment," in Immunity and inflammation in health and disease. Eds. S. Chatterjee, W. Jungraithmayr, and D. Bagchi. San Diego, CA, United States (Academic Press). 241-248. doi: 10.1016/B978-0-12-805417-8.00019-6

Shalita, A. R., Del Rosso, J. Q., and Webster, G., (2011). Acne vulgaris. London: CRC Press. doi: 10.3109/9781616310097

Susilawati, E., Aligita, W., Adnyana, I. K., and Sukmawati, I. K. (2018). Activity of Karehau (Callicarpa longifolia Lamk.) leaves ethanolic extract as a wound healing. J. Pharm. Sci. Res. 10, 1243-1247. 
Taylor, L. A. (1940). Plants used as curatives by certain southeastern tribes. Cambridge, MA: Botanical Museum of Harvard University.

Tellez, M. R., Dayan, F. E., Schrader, K. K., Wedge, D. E., and Duke, S. O. (2000). Composition and some biological activities of the essential oil of Callicarpa americana (L.). J. Agric. Food Chem. 48, 3008-3012. doi: 10.1021/jf991026g

Thiboutot, D., Gollnick, H., Bettoli, V., Dréno, B., Kang, S., Leyden, J. J., et al. (2009). New insights into the management of acne: an update from the Global Alliance to Improve Outcomes in Acne group. J. Am. Acad. Dermatol. 60, S1-50. doi: 10.1016/j.jaad.2009.01.019

Thomas, D. R. (2004). Psychosocial effects of acne. J. Cutan. Med. Surg. 8, 3-5. doi: 10.1007/s10227-004-0752-x

Titus, S., and Hodge, J. (2012). Diagnosis and treatment of acne. Am. Fam. Physician 86, 734-740.

Toyoda, M., and Morohashi, M. (2001). Pathogenesis of acne. Med. Electron. Microsc. 34, 29-40. doi: 10.1007/s007950100002

Tsai, T.-H., Tsai, T.-H., Wu, W.-H., Tseng, J. T.-P., and Tsai, P.-J. (2010). In vitro antimicrobial and anti-inflammatory effects of herbs against Propionibacterium acnes. Food Chem. 119, 964-968. doi: 10.1016/j.foodchem.2009.07.062

Tu, Y., Sun, L., Guo, M., and Chen, W. (2013). The medicinal uses of Callicarpa L. in traditional Chinese medicine: an ethnopharmacological, phytochemical and pharmacological review. J. Ethnopharmacol. 146, 465-481. doi: 10.1016/j. jep.2012.12.051

Van Den Bergh, B., Michiels, J. E., Wenseleers, T., Windels, E. M., Boer, P. V., Kestemont, D., et al. (2016). Frequency of antibiotic application drives rapid evolutionary adaptation of Escherichia coli persistence. Nat. Microbiol. 1, 16020. doi: 10.1038/nmicrobiol.2016.20

Vowels, B. R., Yang, S., and Leyden, J. J. (1995). Induction of proinflammatory cytokines by a soluble factor of Propionibacterium acnes: implications for chronic inflammatory acne. Infect. Immun. 63, 3158-3165.

Walsh, T. R., Efthimiou, J., and Dreno, B. (2016). Systematic review of antibiotic resistance in acne: an increasing topical and oral threat. Lancet Infect. Dis. 16, e23-e33. doi: 10.1016/S1473-3099(15)00527-7

Yang, D., Zhou, C., and Bai, Y. (2010). Clinical research on acne vulgaris treated by Callicarpa nudiflora tablet combined with aadapalene gel. World J. Integr. Tradit. West. Med. 5, 45-47.

Yarnell, E., and Abascal, K. (2006). Herbal medicine for acne vulgaris. Altern. Complement Ther. 12, 303-309. doi: 10.1089/act.2006.12.303

Conflict of Interest: The authors declare that the research was conducted in the absence of any commercial or financial relationships that could be construed as a potential conflict of interest.

Copyright () 2019 Pineau, Hanson, Lyles and Quave. This is an open-access article distributed under the terms of the Creative Commons Attribution License (CC $B Y)$. The use, distribution or reproduction in other forums is permitted, provided the original author(s) and the copyright owner(s) are credited and that the original publication in this journal is cited, in accordance with accepted academic practice. No use, distribution or reproduction is permitted which does not comply with these terms. 